\title{
DOMENTIAN, A SERBIAN HAGIOGRAPHER FROM THE 13th CENTURY ${ }^{1}$
}

\begin{abstract}
:
The article is dedicated to Domentian, an outstanding 13th century Serbian hagiographer, hieromonk of Athos Hilandar monastery. He was the author of the Life of St Sava, Archbishop of Serbia (c. 1170-1235), completed by him in 1243 or 1254. Later, based on it and using a Life written in 1216 by Stefan the First Crowned (1165-1227), he wrote the Life of St Simeon of Serbia. Hagiographic writings of Domentian arose during the heyday of Serbian statehood, they are distinguished by a high panegyric style.
\end{abstract}

\section{Keywords:}

Serbian hagiography, Mount Athos, Hilandar monastery, Hieromonk Domentian, the Lives of Saints Sava and Simeon of Serbia, high panegyric style.

АННОТТЦИЯ: Л.К. ГАВРЮШИНА. «ДОМЕНТИАН, СЕРБСКИЙ АГИОГРАФ ХІІІ В.».

Статья посвящена Доментиану - выдающемуся сербскому агиографу XIII в., иеромонаху афонского Хиландарского монастыря. Он явился автором жития св. Саввы, архиепископа Сербского (ок. 1170-1235), завершенного им в 1243 или в 1254 г. Позднее на его основе и при использовании жития, написанного в 1216 г. Стефаном Первовенчаным (1165-1227), он написал житие святого Симеона Сербского. Агиографические сочинения Доментиана возникли в период расцвета сербской государственности, их отличает высокий панегирический стиль.

\section{Ключевые слова:}

Сербская агиография, афонский Хиландарский монастырь, иеромонах Доментиан, жития святых Саввы и Симеона Сербских, высокий панегирический стиль.

$\mathrm{D}$ omentian is a famous Serbian hagiographer, hieromonk of the Athos Hilandar monastery, a contemporary and disciple of the first Serbian archbishop, Sava of Serbia. Little is known about his life. He was presumably born at the beginning of the 13th century, was of noble birth and received a good education. He apparently took his monastic vows at the Serbian monastery of Zhicha, where he attracted the attention of Archbishop Sava of Serbia, who made him his disciple. Thanks to this, Domentian later often stayed with the saint, accompanied him on his second pilgrimage to the Holy Land in 1233-35, was with him in the Bulgarian capital of Veliko Tarnovo and witnessed Sava's death following a brief illness. Domentian then took part in the burial of the saint and the transfer of his relics to the Serbian monastery of Mileshevo in 1237. Following this, Domentian retired to the Holy Mountain, where he wrote the Lives of St Sava

\footnotetext{
1 The work was carried out with the financial support of the RFBR (grant № 18-512-76004).
} 
and his father, St Simeon the Myrrh-Streaming (whose secular name was Stefan Nemanya), who was the first Serbian Grand prince (zhupan) and the unifier of the Serbian lands.

Domentian's literary gift was highly valued at the Serbian court: both Lives were composed by him at the request of King Urosh I, the grandson of Nemanya and the nephew of St Sava.

Domentian completed the Life of St Sava in 1243 or in 1254 in the Caryes cell, which the ascetic had at one point founded on Mount Athos. Around 1260 he was elected confessor of the Hilandar monastic order, and he settled in the mountains above Hilandar in a place called Spasova Voda. Here, in the tower of the Transfiguration of Christ, the scribe wrote his second hagiographic work in 1263-64, the Life of St Simeon.

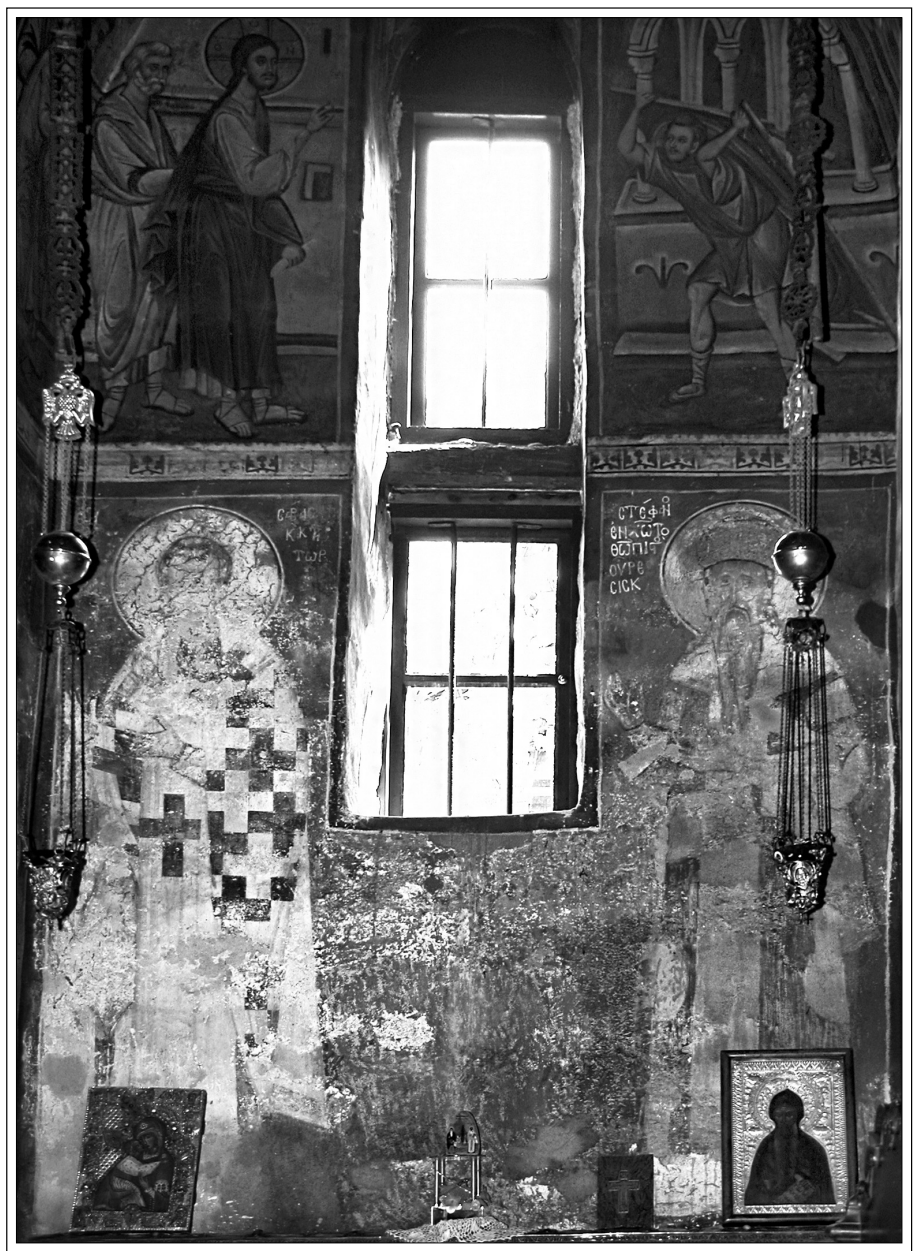

St Sava and St Simeon: worshipers of the main temple at the Hilandar monastery 
These works of Domentian were created during the heyday of Serbian statehood. They are distinguished by their monumentality and highly panegyric style. Praising the national saints who stood at the origins of the renewal of Christian Serbia, the author glorifies it as the "New Israel": in his view, after adopting Christianity, the Serbian people had become God's chosen people. The hagiographer's grandiose artistic design corresponded to his idea of the Serbian saints as the enlighteners of the whole world. The scribe emphasizes their exceptional role in the history of the salvation of mankind through constant reminders of their continuity with respect to the characters of the Old Testament. In the texts of his Lives, Domentian often compares St Sava with the pillars of Old Testament history: Abraham, Isaac, Joseph, Abel, the patriarch Jacob, the prophets Isaiah and John the Baptist. There are especially lengthy comparisons of individual events and miracles from the Life of the first Serbian teacher with those of Moses, the religious leader and first lawgiver of his people. At the same time, Domentian, as a rule, notes how lacking such comparisons are. For him, St Sava ranked incomparably higher than the Old Testament patriarchs and prophets, since he partook in the grace of the New Testament, granted to him by Christ himself.

Of paramount importance to Domentian was the apostolic mission of the saints. In creating the ideal face of the "holy twins", Simeon and Sava, the hagiographer refers to the texts of hymnographic works in honor of the apostles Peter and Paul and often uses the latter's epistles. He does not confine himself to indicating that the saints had been chosen by God; for him the pinnacle of the ideal image of an ascetic is the dogmatically grounded notion of a likeness to God. Therefore, the scribe repeatedly compares St Sava with Christ. In one of his prayers for the resumption of myrrh-streaming from the shrine with the relics of St Simeon, Sava likens his spiritual union with his father to "the unity of the divine," that is, the unity of the Father and the Son. The latter is at the same time the hagiographer's ideal prototype of relations within the church hierarchy. The three representatives of the Nemanich dynasty, St Sava, St Simeon and the son of the latter, St Stefan the First Crowned, are likened to the Holy Trinity. This feature of Domentian's artistic style is due primarily to his theological and symbolic vision of the world. It is one of the manifestations of the principle of the correlation of the earthly and heavenly planes of existence, which is comprehensive for his Lives. The presentation of specific events in the Lives is constantly accompanied by the interpretation of their higher meaning, the ascent to spiritual reality. The compositional structure of these works is determined by the change of monumental poetic images depicting this spiritual reality.

It is not known whether Domentian left behind any hymnographic works, however, his prose often approaches hymnography in its artistic principles. The poetic nature of his narration led to the complexity of the "small" genre forms in the composition of his Lives. For example, the missive with St Sava's appeal to his father to come to him to the Holy Mountain evolves into praise of the latter, and then into a poetic interpretation of the Savior's preaching in the Gospels. 


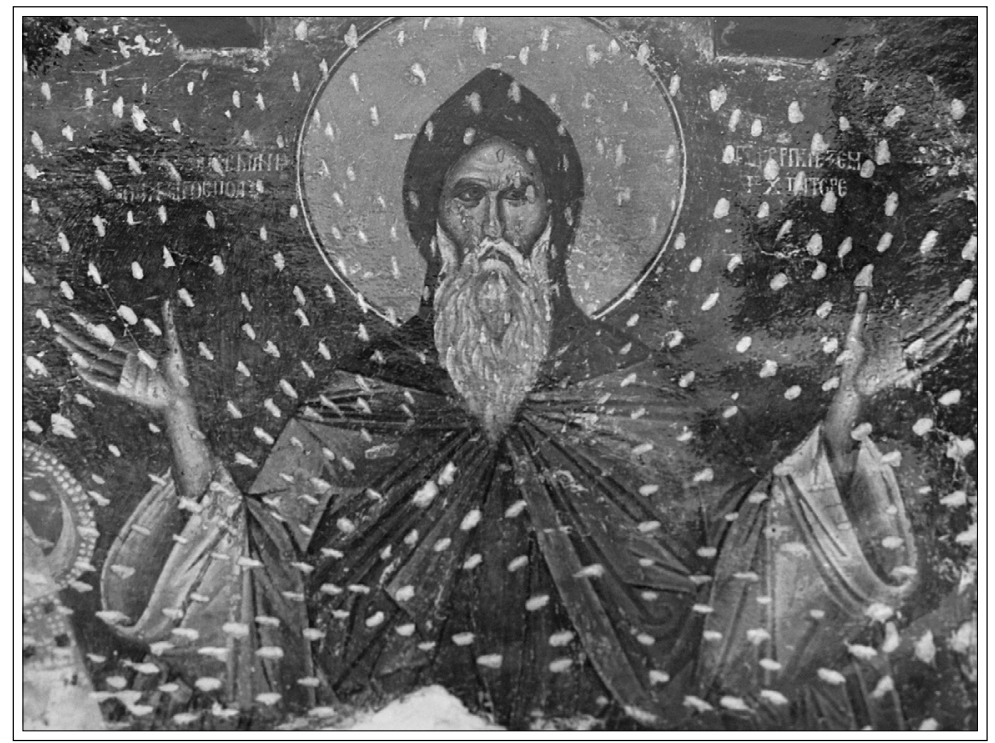

St Simeon of Serbia,

mural painting at the Church of the Virgin (Levish) in Prizren. 1307-09

The style of Domentian's works is characterized by a wealth of rhetorical figures, syntactic "extensions" in the construction of phrases, attention to the aspect of how the words sound. His widely used principles of the "weaving of words" style are at the service of "poetic theology."

It should be noted that the Life of St Sava surpasses in volume all of the medieval Serbian biographies (about 200 pages) and is one of the most significant and complex works of ancient Serbian literature. In this essay consisting of 33 chapters, the biography of the first Serbian hagiographer was presented fully for the first time. It contains the texts of valuable historical documents processed by the hagiographer: the charter of the proclamation of autocephaly of the Serbian Church and a number of St Sava's epistles and sermons. The scribe puts many of the statements about St Sava into the mouths of the characters/ witnesses: the elder Macarius, the spiritual father of Sava, the Byzantine emperor, the Jerusalem patriarch Athanasius, etc.

One of the main sources in the compilation of this work by Domentian was a brief Life of St Sava created by an anonymous author in Hilandar and then revised in the Mileshevo monastery. By incorporating this text into a new rhetorical-panegyric artistic context, Domentian enriched it with new facts from his personal impressions and oral legends about Sava. Central to the scribe's narrative is the story of the election of Sava as archbishop and the creation of the autocephalous Serbian Church. The author attaches considerable importance to the story of church law (the compilation of the Karyes Tipicon and Pilot (in Slavic "Kormchaya"), the organization of dioceses, the election of bishops) 
and the saint's diplomatic activity. The story of Sava's visit to the holy places of Palestine, Egypt, Sinai and Antioch also has great spiritual and symbolic meaning. In speaking about the asceticism of St Sava and his father, Simeon Nemanya, on Mount Athos, the author provides detailed information about the Athos monasteries, hermitages and the life of hermits. He tells the reader how Hilandar arose and was built. The oldest copy of the Life of St Sava, edited by Domentian, dating from the 1420s-1430s, is stored in the Russian National Library of St. Petersburg.

When writing the Life of St Simeon, Domentian used both his own Life of St Sava as well as the text, Life of Stefan Nemanya, which was written in 1216 in honor of his father by the elder brother of Sava, King Stefan the First-Crowned (1165-1227). The scribe borrowed one-third of the text from the first and more than 400 lines from the second. It is no coincidence that he turned to the text of Praise to Prince Vladimir from a monument of the Old Russian literature of the 11 th century, The Word on the Law and the Grace by the Metropolitan of Kiev, Hilarion. Like Sava and Stefan Nemanich later in Serbia, this Russian prince played a primary role in Russia in rooting the teachings of Christ. The oldest Slavic manuscripts with the texts of Domentian's Life of St Simeon belong to the third or fourth quarter of the 14th century and are stored in the libraries of Odessa University, the National Serbian and Romanian Academy of Sciences.

Reflective of the Holy Mountain in spirit and at the same time intended for the court, both works by Domentian are united by the idea of creating a Christian kingdom under the protection of national saints who are representatives of the same dynasty and combine spiritual and secular principles in their activities.

Translated by Igor Kaliganov

\section{BIBLIOGRAPHY}

Srećković P. Tvorenia Domentiana i Teodosia // Spomenik Srpske Kraljevske Akademije. XXXIII. 2 razred. Belgrade, 1898. S. 65-120.

Stanojević S. Izvori Nemaninjih biografija // Letopis Matice Srpske. Knj. 181. Belgrade, 1895. Sv. II. S. 101-102.

Život Svetoga Simeuna i Svetoga Save. Napisao Domentijan. Na svijet izdao Đ. Daničić. Belgrade, 1865.

\section{ILLUSTRATIONS $^{2}$}

1. The Monastery of Zhicha, Serbia.

2. The Hilandar monastery, Mount Athos, Greece.

3. The Monastery of Mileshevo, Serbia.

4. St Simeon of Serbia, mural painting at the Church of the Virgin (Levish) in Prizren. 1307-09.

5. St Sava and St Simeon: worshipers of the main temple at the Hilandar monastery.

\footnotetext{
${ }^{2}$ Here and bellow are the illustrations that will be posted on the site. In this issue are published only some of them. Their full list can be seen on pages 345-48.
} 